\title{
SEISMIC ISOLATION OF A PRINTING PRESS IN WELLINGTON, NEW ZEALAND
}

\author{
D. J. Dowrick', J. Babor ${ }^{2}$, W. J. Cousins ${ }^{3}$ and R. I. Skinner ${ }^{4}$
}

\author{
This paper was presented at the \\ Pacific Conference on Earthquake Engineering, \\ Auckland \\ November 1991
}

\section{SUMMARY}

\begin{abstract}
This paper describes the seismic hazard near the Wellington Fault in Petone, and the measures taken to protect a new printing press made of brittle cast iron against earthquake attack. The printing press, owned by Wellington Newspapers, was located just $20 \mathrm{~m}$ from the Wellington Fault. Mounting the specially designed building housing the press on a seismic isolation system, lead-rubber bearings, reduced the estimated loads and deflections on the press by a factor of 8-10 compared with the non-isolated case. As a result the press should suffer only modest damage in earthquake shaking somewhat stronger than that required by the New Zealand earthquake code for the design of buildings.
\end{abstract}

\section{INTRODUCTION}

In 1988 Wellington Newspapers Ltd approached the DSIR seeking advice on earthquake protection for a proposed new printing press establishment to be built in the Wellington Region at Petone. The need for special protection of cast iron press machines had been demonstrated by the vulnerability of paper machines in the 1987 Edgecumbe earthquake [5]. The site for this project was chosen because of its ready access to rail and road transport, but turned out to be traversed by the Wellington Fault [2]. This paper first describes the seismic hazard assessment of the site, and then discusses the seismic protection that was devised in collaboration with the project design team Tse Group, Architects Engineers and Surveyors, and with Wellington Newspapers.

\section{SEISMIC SETTING OF THE PETONE SITE}

The site is located in New Zealand's most active seismic region. The driving force for seismic activity is the crustal strain set up by interaction on the interplate boundary beneath the Wellington region where the Pacific Plate is subducting beneath the Australian Plate. This process gives rise to earthquakes on, below, and above the plate interface. Visual geological evidence of this activity is found in the surface expression of several major active faults in the region, of which the Wellington Fault runs through the study site. The four most hazardous faults in the region plus the subduction zone interface, were considered for design purposes in this study. As shown in Table 1, these faults are expected to generate magnitudes of 7.5 to 8.5 .

\footnotetext{
${ }^{1,2,3,4}$ DSIR Physical Sciences, Lower Hutt

${ }^{1}$ Fellow

${ }^{3}$ Member

${ }^{4}$ Life Member
}

\section{UNIFORM RISK AND SCENARIO APPROACHES TO SEISMIC HAZARD ASSESSMENT}

The estimation of the seismic hazard at the Petone site was approached in two ways. Firstly, in the uniform risk approach, a seismicity model developed by Smith and Berryman [11] was used to estimate the average number of events per annum in various magnitude and epicentral distance ranges likely to affect the site. In this seismicity model, the country is divided into a number of seismic source regions, with the activity distributed uniformly within a region rather than concentrated on geological or tectonic features such as major faults. An attenuation model is then used to predict the strength of shaking at the site likely from events in each of the magnitude and epicentral distance classes with the results expressed in terms of uniform-risk 5\%damped acceleration response spectra for various return periods. Such spectra have been presented for sites throughout New Zealand by a Seismic Risk Committee (SRC) [8]. The uniform risk spectrum for the Petone site derived from the SRC is given for a return period of 220 years by Curve 1 in Fig. 1. This curve is classified by the SRC for their ground class 3 (GC3) site condition which corresponds to our alluvial site at Petone.

For comparison we also present in Figure 1 (Curve 2) the uniform risk spectrum for a 220 year return period derived from the draft loadings code DZ4203 [12]. This curve is closely similar (except at short periods) to that of the SRC, on whose data DZ4203 was based.

The second approach used for estimating hazard at the Petone site was the development of scenarios which consider the motions likely to occur at the site during earthquakes on various faults in the region. This approach was more deterministic in nature than that given above in that individual events were considered explicitly, but the results could still be expressed in probabilistic terms, taking into account uncertainties and scatter in the recurrence interval of events and in the strength of shaking associated with an event of given magnitude and distance from the site. 
Table 1: 1988 Data on Active Faults in the Wellington Area

(Some of this data is now subject to moderate revision)

\begin{tabular}{|c|c|c|c|c|c|c|c|}
\hline \multirow[t]{2}{*}{ Fault } & \multirow[t]{2}{*}{$\begin{array}{c}\text { Expected } \\
\text { Mag. }\end{array}$} & \multirow[t]{2}{*}{$\begin{array}{c}\text { Shortest } \\
\text { Distance } \\
\text { from } \\
\text { Fault } \\
(\mathrm{km})\end{array}$} & \multirow[t]{2}{*}{$\begin{array}{l}\text { PGA } \\
(\mathrm{g})\end{array}$} & \multirow[t]{2}{*}{$\begin{array}{c}\text { Mean* } \\
\text { Recurrenc } \\
\text { e Interval } \\
\text { (yrs) }\end{array}$} & \multirow[t]{2}{*}{$\begin{array}{c}\text { Time* } \\
\text { since last } \\
\text { movement } \\
\text { yrs) }\end{array}$} & \multicolumn{2}{|c|}{$\begin{array}{c}\text { Probability } \\
\text { of movement } \\
\text { in next } \\
50 \text { years (\%) }\end{array}$} \\
\hline & & & & & & Range & $\begin{array}{l}\text { Median } \\
\text { value } \\
\text { used in } \\
\text { this study }\end{array}$ \\
\hline $\begin{array}{l}\text { Shepherds } \\
\text { Gully }\end{array}$ & 7.5 & 13 & 0.40 & 3000 & 1500 & $1-2$ & 1.5 \\
\hline Ohariu & 7.5 & 9 & 0.45 & 3000 & 1500 & $1-2$ & 1.5 \\
\hline Wellington & 7.5 & 0 & 0.70 & 560 & $300-700$ & $7-24$ & 15.5 \\
\hline Wairarapa & 8.3 & 18 & 0.45 & 1500 & 133 & $<1$ & 0.5 \\
\hline $\begin{array}{l}\text { Subduction } \\
\text { Zone }\end{array}$ & 8.5 & $\begin{array}{c}30 \\
\text { vertical }\end{array}$ & $0.2-0.5 ?$ & $\nabla$ & $\nabla$ & $\nabla$ & $(1.5)$ \\
\hline
\end{tabular}

Notes: ( ) Value in brackets assigned for this study.

* Data on fault movements supplied by NZ Geological Survey in 1988

$\nabla \quad$ Values not known.
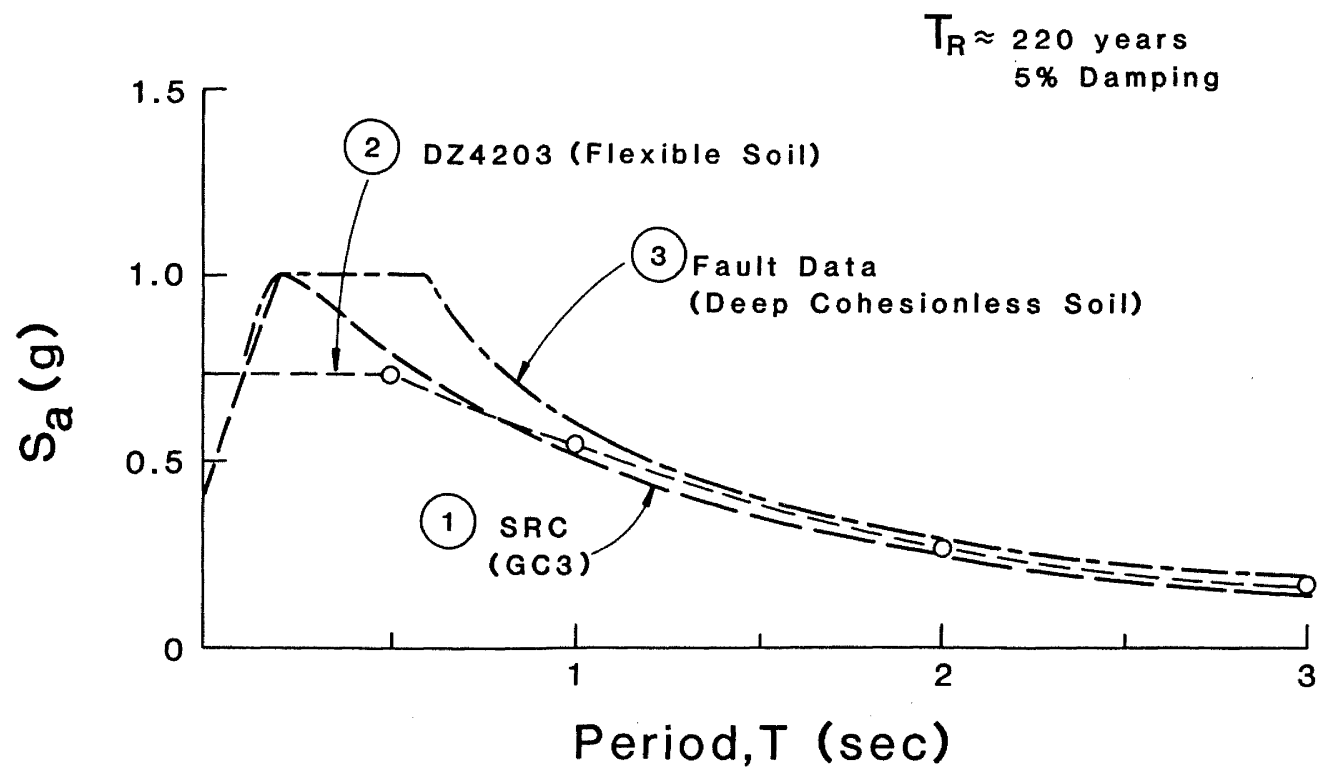

Figure 1: Response spectrum from fault data v. uniform risk spectra for Petone site. 
In the absence of an established New Zealand expression for the attenuation of peak ground acceleration (PGA), expressions from three overseas studies $[3,6,7]$ were used in conjunction with the magnitude and distance data from Table 1 . From these results a rounded mean PGA for the site was estimated for each source fault, also given in Table 1.

Using the fault movement data in Table 1, it followed that for the Wellington Fault the annual probability of occurrence was about $\left.3.5 \times 10^{-3}\right)$, corresponding to an average return period $\mathrm{T}_{R}$ of about $1 /\left(3.5 \times 10^{-3}\right)$ or 300 years. Also, using all the accelerations and the probabilities of fault rupture given in the table, it was found that the annual probability of $\mathrm{a}_{\max } \geq 0.4 \mathrm{~g}$ occurring at the site was $4.5 \times 10^{-3}$. Thus the return period of $\mathrm{PGA} \geq 0.4 \mathrm{~g}$ at the site was about $1 /\left(4.5 \times 10^{-3}\right)$ or 220 years.

In order to obtain response spectra matching the site conditions and the above peak ground accelerations we used a smoothed spectral shape derived from a suitable suite of earthquakes, specifically the mean curve for deep cohesionless soils proposed by Seed and Idriss [9]. We thus found the spectral accelerations, $S_{a}$, for the given $a_{\max }$ values, i.e.

$$
\begin{array}{ll}
\mathrm{T}=0.2-0.6 \mathrm{~s}, & \mathrm{~S}_{\mathrm{a}}=2.5 \mathrm{a}_{\max } \\
\mathrm{T}=1.0 \mathrm{~s}, & \mathrm{~S}_{\mathrm{a}}=1.5 \mathrm{a}_{\max } \\
\mathrm{T}>1.0 \mathrm{~s}, & \mathrm{~S}_{\mathrm{a}} \text { inversely proportional to } \mathrm{T}
\end{array}
$$

The resulting spectrum for the return period of 220 years is plotted on Fig.1 (Curve 3). This spectrum is $15 \%$ or more stronger than that of the SRC. The response spectrum for the Wellington Fault itself (not shown here) was about twice as strong as that derived for the appropriate return period from the uniformly distributed seismicity model of the SRC.

We adopted the fault data spectra, Curve 3, as giving a truer representation of the hazard at the Petone site, than that obtained from the uniformly distributed seismicity model.

\section{SELECTION OF EARTHQUAKE ACCELEROGRAMS}

The design of the seismically isolated structure was based on dynamic analyses using earthquake acceleration records as the input excitations. The authors selected appropriate records which matched the target design spectra determined above, i.e. Curve 3 on Fig.1., bearing in mind that the important part of the target spectrum to match was in the vicinity of the fundamental period of vibration $\left(T_{1}\right)$ of the isolated structure. As the system had been designed so that $T_{1}=2.0 \mathrm{~s}$, it was necessary to scale the earthquake records to have spectral accelerations $S_{a}$ (at $T=2.0 \mathrm{~s}$ ) as follows:

Table 2

\begin{tabular}{|c|c|}
\hline Target Design Spectra & $\mathrm{S}_{\mathrm{a}}(\mathbf{T}=\mathbf{2 . 0})$ \\
\hline Wellington Fault $\left(\mathrm{T}_{\mathrm{R}} \approx 300 \mathrm{yrs}\right)$ & $0.52 \mathrm{~g}$ \\
Other Faults $\left(\mathrm{T}_{\mathrm{R}} \approx 220 \mathrm{yrs}\right)$ & $0.30 \mathrm{~g}$ \\
\hline
\end{tabular}

For design earthquakes we chose three records as follows:

(1) Imperial Valley 1940 earthquake; El Centro (N-S component);

(2) Kern County 1952 earthquake; Taft Lincoln School (S69E component);

(3) San Fernando 1971 earthquake; Pacoima Dam (S14W component).
To match the target spectra the records had to be scaled by the factors given in Table 3 , columns (a) and (b).

Table 3: Design Accelerograms with scale factors matching target spectra at $\mathrm{T}=2.0 \mathrm{~s}$

\begin{tabular}{||c|c|c|c||}
\hline \multirow{4}{*}{ Record } & \multicolumn{3}{|c||}{ Scale Factors } \\
\cline { 2 - 4 } & $\begin{array}{c}\text { (a) Wellington } \\
\text { Fault }\end{array}$ & \multicolumn{2}{|c|}{$\begin{array}{c}\text { Other Faults } \\
\mathrm{T}_{\mathrm{R}} \approx 220 \text { years }\end{array}$} \\
\cline { 2 - 4 } & $\mathrm{T}_{\mathrm{R}} \approx 300$ yrs & (b) Initial & (c) Final \\
\cline { 3 - 4 } & & 1.69 & 2.0 \\
El Centro (NS) & 2.92 & 3.49 & 4.14 \\
Taft (S69E) & 6.05 & 0.617 & 0.53 \\
Pacoima (S14W) & 1.07 & & \\
\hline
\end{tabular}

\section{DYNAMIC ANALYSES}

A typical cross-section of the structural system is shown in Fig. 2. To given the printing presses maximum protection from earthquakes, the building required a seismic isolation system, and in addition the building had to be as stiff as possible up to the top of the presses to limit the horizontal deflections of the presses in all directions. The authors therefore recommended that the originally proposed concrete walls should be extended in height and length around the ends of the press room, and also proposed stiffening the mezzanine floor. Creating enough horizontal stiffness in the direction lateral to the presses as the top platform level proved to be particularly difficult because visibility required for operations necessitated the use of a horizontal steel truss at this level (rather than using an opaque concrete slab). It was not practicable to create a truss with the optimum desired stiffness, but a workable solution was found.

The dynamic analyses were carried out using a computer program developed by J. Babor and R.I. Skinner specially for analysing seismically isolated structures. The above structural system was modelled with satisfactory realism for the computer analyses, with the model incorporating the non-linear behaviour of the special isolating and damping system introduced below the ground floor. The approximate non-linear behaviour of the isolation system is illustrated by the hysteresis loop in Fig 3. The shape of the hysteresis loop had considerable effect on the responses of the structure, as shown in Fig 4, which was plotted from the results of sensitivity studies carried out by altering the isolator's stiffness and damping, and using the El Centro and Pacoima records as input. The most favourable behaviour is seen in Fig 4 to be that where the bearings have a hysteresis loop in which the steep "first" slope is such that $\mathrm{T}_{\mathrm{b} 1}=0.9 \mathrm{~s}$, where $\mathrm{T}_{\mathrm{b} 1}$ is a parameter with the form and dimensions of $\mathrm{a}$ period of vibration, as described elsewhere [10]. The bearings used in the building were designed so as to have this preferred behaviour.

From the results of the first trial analyses it was found that the horizontal accelerations applied to the isolated structure due to the very strong shaking caused by a rupture on the Wellington Fault (Table 3(c)) would be in the range approximately $0.4 \mathrm{~g}$ $0.6 \mathrm{~g}$. It would have been both expensive and physically very difficult to give a high level of protection to the press against damaging deflections under such forces, particularly at the upper platform level. An additional disadvantage arose from the fact that it was not feasible operationally to apply any lateral restraint to the press at a level midway between the top platform and the mezzanine floor. 


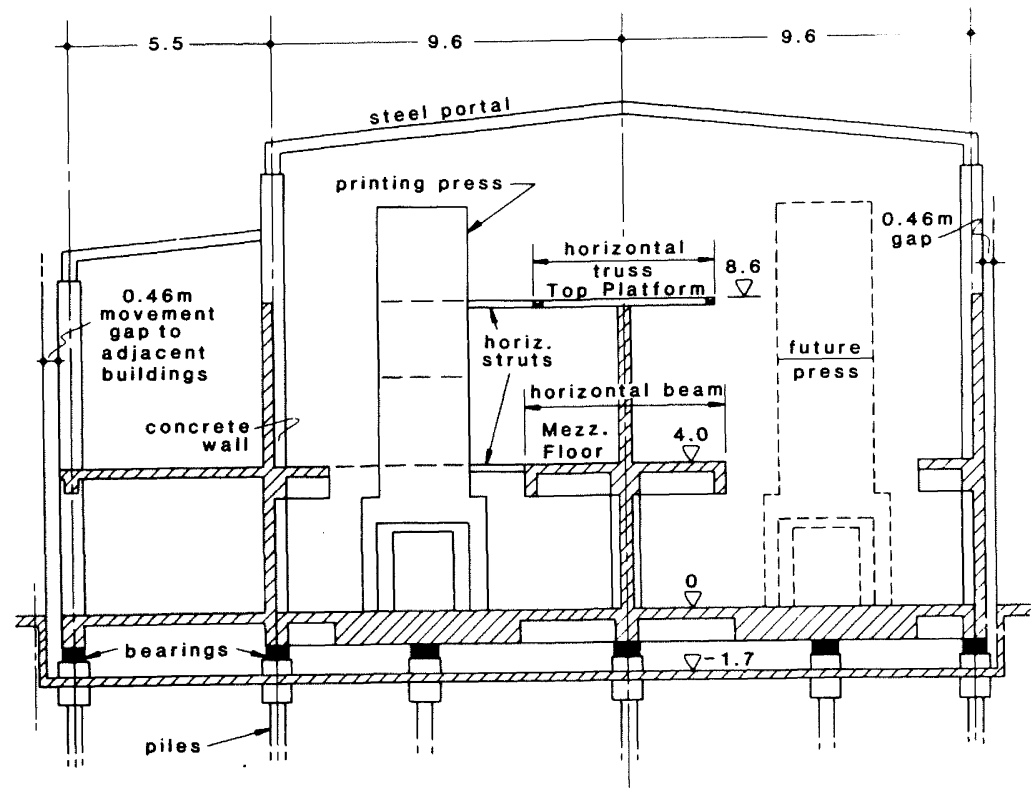

Figure 2: Section through press hall structure near end walls.
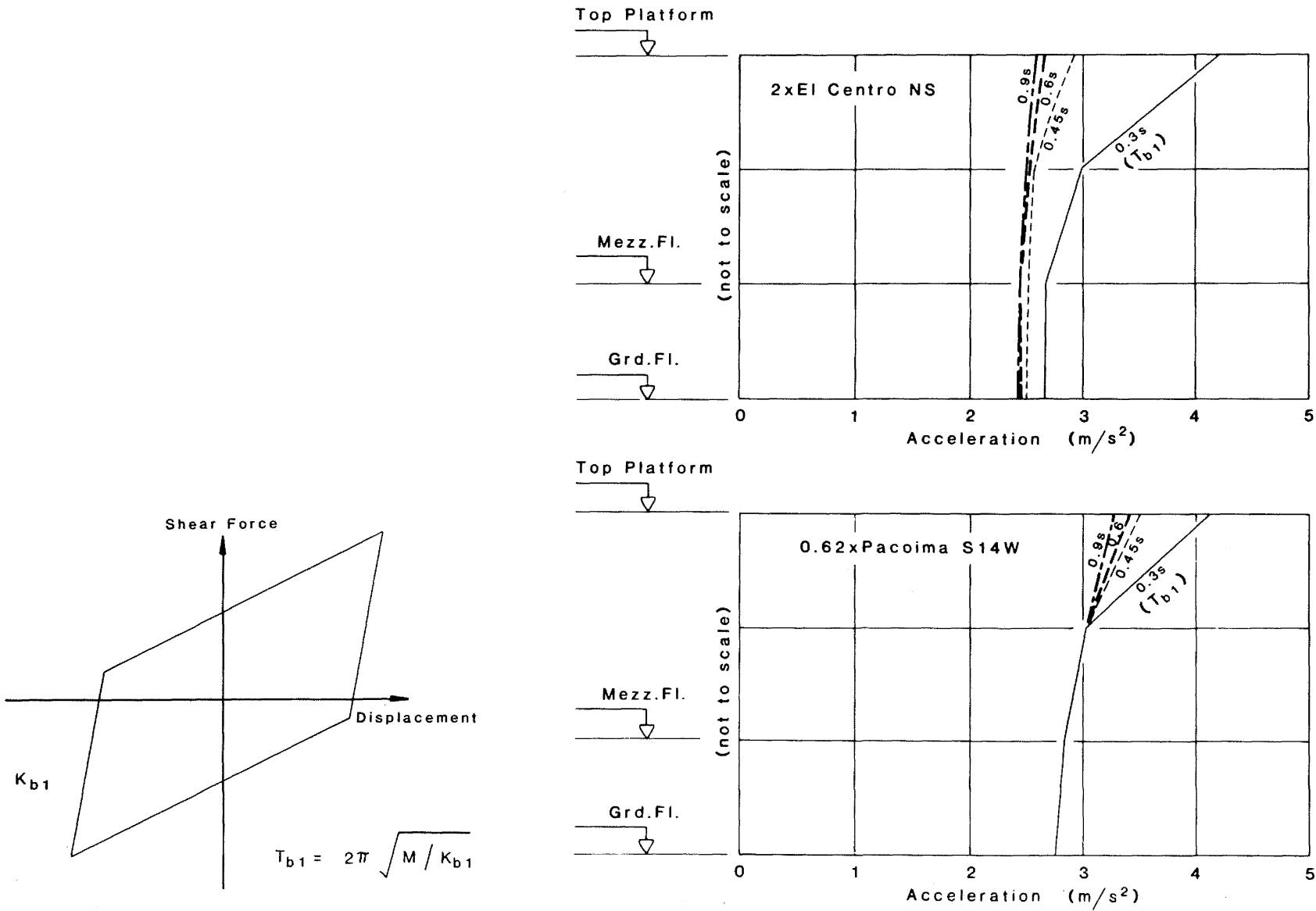

Figure 3: Analytical model of hysteresis loop of leadrubber bearings.
Figure 4: Maximum accelerations lateral to press. Sensitivity analysis of bearing properties. 
Nevertheless it was apparent that somewhat reduced but still strong ground shaking could be dealt with. It was therefore decided to investigate what maximum level of protection could reasonably be provided within the constraints determined by the geometry of the building and the operation of the press, by considering the accelerograms scaled for the return period of 220 years (Table $3(b)$ ).

After some further trial analyses and structural checks, it was found practicable to provide protection against earthquake generated accelerations transmitted through the structure of about $0.3 \mathrm{~g}$ at the top of the press and $0.25 \mathrm{~g}$ at lower levels. Such accelerations in the structure were generated by the ground motion records given in Table 3(c). Comparing Tables $3(\mathrm{~b})$ and (c), it is seen that to obtain the above structural forces, it was necessary to increase by $18 \%$ the scaling of the El Centro and Taft records given on Table $3(\mathrm{~b})$, and decrease the scaling factor for Pacoima by $14 \%$. This implies that the near-source Pacoima record is more powerful in generating forces in our non-linear isolated system than are the other two earthquake records. This effect is explained by the presence of relatively long-duration acceleration pulses in the Pacoima record. Such pulses have been observed in a number of near-source records in recent years, and it has been shown [1] that their effects on yielding structures are relatively severe, and hence need particular attention when structures are close to active faults.

In our case, as we were forced to forego full protection against rupture of the Wellington Fault, the next nearest fault to the site was the Ohariu Fault, $9 \mathrm{~km}$ away. It was not known how likely it was for long duration pulses to exist at a distance of $9 \mathrm{~km}$ from the rupturing surface, but this may be near the limit in distance at which they will occur. However, we deemed it wise to allow for such pulses to the extent given by designing against $0.53 \times$ Pacoima.

\section{SEISMIC FORCES LOADS AND STRESSES}

As noted above it was proposed that the earthquake forces in the main structure should be calculated assuming that the horizontal accelerations were $0.3 \mathrm{~g}$ at the top platform level of the presses and $0.25 \mathrm{~g}$ at lower levels. Such forces were applied both longitudinally and laterally but not simultaneously in these two directions. To limit the horizontal deflections and therefore stresses, in the presses, the authors recommended that the structure be designed elastically using the working stress approach. The stresses at the above loads were limited to $\leq$ $0.9 \mathrm{f}_{\mathrm{y}}$ for rebars and to $\leq 0.8 \mathrm{f}$ (permissible) in the steel truss. The longitudinal reinforcing steel was to be Grade 380, and not Grade 275 , so as to avoid the higher deflections caused by the flat yield plateau of "mild" steel if yield stress is exceeded in stronger shaking than that assumed in the design.

\section{PROTECTION ACHIEVED BY SEISMIC ISOLATION}

We predict that the earthquake forces and deformations applied to the presses will be greatly reduced by the seismic isolation system, compared with those that would occur in a conventional structure. This improvement is illustrated in broad terms by comparing the effects of applying the ground motions of $2 \times \mathrm{El}$ Centro to the isolated and the unisolated (i.e. fixed-base) models. The accelerations and inter-level displacements for the two models are compared in Fig 5, which shows that the accelerations experienced at the top of the press would be about 9 times higher in the unisolated case than in the isolated case, assuming that the structure remained elastic. In fact, as the acceleration calculated for the fixed-base model was $2.4 \mathrm{~g}$ at the top of the press, the press and much of the supporting structure would have failed before such large accelerations were reached.
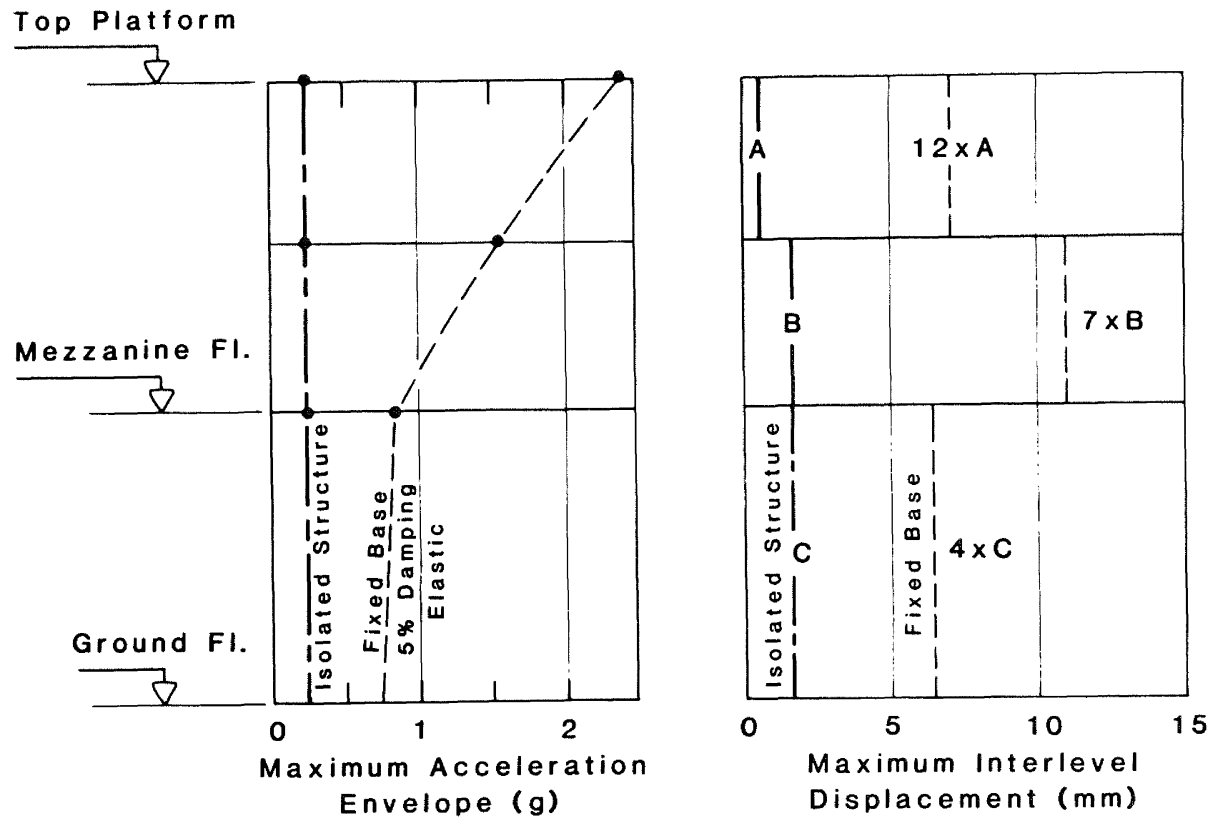

Figure 5: Comparison of isolated and fixed-base structures under $2 \times$ El Centro shaking. 
This comparison is supported by the differences in the interlevel horizontal displacements immediately below the top platform which, as shown in Fig 5, are 12 times greater in the unisolated case. The actual inter-level deflections predicted in the fixed-base case are $10 \mathrm{~mm}$ and $7 \mathrm{~mm}$ for the two platform levels of the press above the mezzanine floor. Clearly the press would fail under such deformations.

The actual inter-level deformations are predicted not to exceed about $1.5 \mathrm{~mm}$ in the isolated building when subjected to $2 \mathrm{x}$ El Centro. While a reliable prediction of the behaviour of the press under these deformations is not possible, the authors consider that damage would almost certainly be modest in this case.

\section{DESIGN OF THE ISOLATION SYSTEM}

The isolation system could have used one of three different but related sets of devices:

(a) Lead rubber bearings;

(b) Standard elastomeric bearings plus steel dampers;

(c) Standard elastomeric bearings plus lead-extrusion dampers.

For this particular building we found a combination of leadrubber bearings and standard elastomeric bearings to be suitable technically and to be the cheapest option, located as seen in Fig 2. In order to obtain the required initial and overall flexibility the structure needed lead-rubber bearings that were much thicker (at $460 \mathrm{~mm}$ ) than any used or tested before. Hence tests of two prototype bearings were carried out [4] which confirmed the design properties of the bearings for use in the design.

\section{CONCLUSIONS}

1. Seismic isolation provides the brittle cast-iron printing presses with considerable protection against strong earthquakes, a protection that could not be provided with conventional construction.

2. The press building was designed not to yield in events corresponding to an average return period of 220 years. These events were the following scaled real events: 2.0 times El Centro (NS); 4.14 times Taft (S69E); 0.53 times Pacoimo (S14W).

These motions all have spectral accelerations at the fundamental period of the isolated structure $\left(\mathrm{T}_{1}=2.0 \mathrm{~s}\right)$ of $\mathrm{S}_{\mathrm{a}} \approx 0.3 \mathrm{~g}$, and peak ground accelerations $\mathrm{a}_{\max } \approx 0.7 \mathrm{~g}$.

3. The expected worst shaking at the site was that due to a movement of the immediately adjacent Wellington Fault, with a mean spectral acceleration of $S_{a} \approx 0.52 \mathrm{~g}$ at the fundamental period of $T_{1} \approx 2.0 \mathrm{~s}$. It was found to be unfeasible to fully protect the press against such motions, because of geometric constraints imposed by the building plan and by operational requirements.

4. The strength of shaking close to the rupture of the Wellington Fault is seriously underestimated by the uniformly distributed hazard approach of the proposed revision of the New Zealand loadings code DZ4203.

5. The near-source Pacoima Dam record is more damaging to the non-linearly responding system than the El Centro and Taft records scaled to the same elastic spectral acceleration at the fundamental period of the isolated structure.

\section{ACKNOWLEDGEMENTS}

The authors wish to thank Wellington Newspapers Ltd and Tse Group Ltd, in particular A Darbyshire and R Bryant, for their creative collaboration in this project.

\section{REFERENCES}

1. Anderson, J.C., and Bertero, V.V. 1987. "Uncertainties in establishing design earthquakes". Jnl. of Structural Engineering 113(8): 1709-1724.

2. Beanland, S. 1988. "Location of the Wellington fault at Richmond Street, Petone". NZ Geological Survey Report to Wellington Newspapers Ltd.

3. Campbell, K.W. 1981. "Near-source attenuation of peak horizontal acceleration". Bulln. of the Seismological Society of America, 71(6): 2039-2070.

4. Cousins, W.J., Robinson, W.H., and McVerry, G.H. 1992. "Recent development in devices for seismic isolation". Bulln. NZ Nat. Soc. for Earthq. Eng. 25(3).

5. Hodge, W.C., and Macfarlane, M. 1988. "Effect of the Edgecumbe earthquake on mechanical and process equipment at the Tasman Mill". Bulln. NZ National Soc. for Earth. Eng., 21(3): 161-173.

6. Idriss, I.M. 1985. "Evaluating risk in engineering practice". Proc. 11th Intl. Conf. on Soil Mech. and Foundation Eng., San Francisco, 1: 255-320.

7. Joyner, W.B., and Boore, D.M., 1981. "Peak horizontal acceleration and velocity from strong-motion records including records from the 1979 Imperial Valley, California, earthquake". Bulln. Seism. Soc. of America 71(6): 2011-2038

8. Matuschka, T., Berryman, K.R., O'Leary, A.J., McVerry, G.H., Mulholland, W.M., and Skinner, R.I. 1985. "New Zealand seismic hazard analysis". Bulln. NZ Natl. Soc. for Earthq. Eng. 18(4): 313-322.

9. Seed, H.B. and Idriss, I.M. 1982. "Ground motions and soil liquefaction during earthquakes". Earthquake Engineering Research Institute.

10. Skinner, R.I., and McVerry, G.H., 1988. "Preliminary design of base-isolated structures". Proc. 9th World Conf. on Earthq. Eng., Tokyo, VIII: 409-414.

11. Smith, W.D. and Berryman, K.R. 1983. "Revised estimates of earthquake hazard in New Zealand". Bulln. NZ Nat. Soc. for Earthq. Eng. 16(4): 259-272.

12. Standards Association of New Zealand, 1989. "Draft revision of New Zealand loadings code. DZ4203". 